\title{
Cell surface properties of Clostridium difficile: haemagglutination, relative hydrophobicity and charge
}

\author{
M. M. KRISHNA*, N. B. L. POWELL and S. P. BORRIELLO \\ Microbial Pathogenicity Research Group, Institute of Infections and Immunity and Division of Microbiology, \\ Queen's Medical Centre, Nottingham NG7 2UH
}

\begin{abstract}
Five well characterised strains of Clostridium difficile of differing virulence and two Escherichia coli strains, a verotoxigenic 0157:H7 isolate and a urinary isolate, were examined for cell surface hydrophobicity and charge, and haemagglutinating ability. Phase partition in hexadecane or octan-1-ol was similar for $C$. difficile and $E$. coli, as was retention by hydrophobic interaction chromatography (HIC), indicating moderate hydrophobicity. The salt agglutination test showed $E$. coli to be hydrophobic and $C$. difficile to be hydrophilic. Relative hydrophobicity determined by HIC when charge effects were not nullified, i.e., to reflect more closely conditions in vivo, showed $C$. difficile to bind less well. Growth of $C$. difficile in caecal emulsions to simulate conditions in vivo did not alter the cell surface hydrophobicity. The phase partition method for charge determination indicated that $E$. coli and $C$. difficile had a net negative charge, although this was weaker for $C$. difficile than $E$. coli. However, although $E$. coli exhibited a net negative charge as determined by immuno-gold electronmicroscopy (IGEM), in keeping with the results of the phase partition method, C. difficile was shown to be predominantly positively charged by IGEM, and by movement in a charged field as determined by paper electrophoresis and a novel method based on light microscope observation. A cell-wall deficient mutant of $C$. difficile was weakly positively charged, showing that most of the charge resides in the cell wall.
\end{abstract}

\section{Introduction}

Clostridium difficile is an important nosocomial enteric pathogen, causing pseudomembranous colitis and many cases of antibiotic-associated diarrhoea $[1,2]$. Various established and putative virulence factors have been described [3]. These are mainly toxins A and B [4], but also include factors such as capsule production [5], which may confer protection against phagocytosis, and production of general and tissue degradative proteases, e.g., collagenase and hyaluronidase [6,7]. Apart from the toxins most work has centred on adherence as a colonisation and putative virulence factors. $C$. difficile can adhere to the colonic mucus of man [8] and hamsters [9], and there is a positive correlation between the ability to adhere in vivo and virulence [9]. More recently, $C$. difficile has been shown to adhere to the cultured intestinal cell lines Caco-2 and HT29-MTXC

Received 31 March 1995; revised version accepted 9 Aug. 1995.

*Present address: Department of Microbiology, DNAX Research Institute, 901 California Avenue, Palo Alto, California 94304-1104, USA.

Corresponding author: S. P. Borriello.
[10]. This cell-culture adhesion is associated with $27-\mathrm{kDa}$ and $40-\mathrm{kDa} C$. difficile proteins, which have now been cloned [11]. $C$. difficile has been shown to produce fimbriae [12], which are potential mediators of adhesion, although these do not appear to be related to the $27-\mathrm{kDa}$ and $40-\mathrm{kDa}$ putative adhesion proteins [10]. However, the nature of the host receptor for $C$. difficile in any of these systems, if a specific receptor be involved, is unknown. Also, only limited information is available on the physicochemical characteristics of the bacterial cell surface of $C$. difficile that may be involved in the adhesion process, and none after growth in media that more closely resemble the situation in vivo. This study was undertaken to identify and characterise two physicochemical parameters that may be involved in mediating adhesion, namely cell surface hydrophobicity and cell surface charge, and to use the commonly applied haemagglutination assay for the identification of putative carbohydrate receptors.

\section{Materials and methods}

Bacterial strains and culture conditions

Five well characterised strains of $C$. difficile and two 
Escherichia coli strains were used. The $C$. difficile strains were $\mathrm{M}-1$, a non-toxigenic avirulent strain [13]; BAT, a weakly virulent toxigenic strain [14]; B-1, a highly virulent toxigenic strain [14]; VPI 10463, a highly virulent toxigenic strain (made available by $\mathrm{Dr}$ D. Lyerly, Virginia Polytechnic Institute); and 8864, a less virulent cytotoxigenic strain that fails to produce toxin A [15]. Strain B-1 adheres strongly to hamster gut mucus, and strains M-1 and BAT adhere poorly [9]. The $E$. coli strain U1 was isolated from urine (Department of Microbiology, Northwick Park Hospital) and strain 0157:H7 is a verotoxigenic strain isolated from faeces (Enteric Reference Laboratory, CPHL, Colindale Avenue, London). The bacteria were cultured in Brain Heart Infusion (BHI) Broth (Unipath) for $18 \mathrm{~h}$ at $37^{\circ} \mathrm{C}$, in an atmosphere of $\mathrm{CO}_{2} 10 \%, \mathrm{H}_{2}$ $10 \%$ and $\mathrm{N}_{2} 80 \%$ for $C$. difficile in an anaerobic cabinet (Forma Scientific, Marietta, OH, USA) and aerobically for $E$. coli. The broths were then centrifuged at $1500 \mathrm{~g}$ for $20 \mathrm{~min}$ at $4^{\circ} \mathrm{C}$, the pellets were resuspended in $10 \mathrm{ml}$ of fresh $\mathrm{BHI}$ broth, and $0.1 \mathrm{ml}$ was used to seed $10 \mathrm{ml}$ of the following growth media: filtrates (filter pore size $0.45 \mu \mathrm{m}$ ) of an aqueous $5 \%$ suspension of caecal contents from hamsters pre-treated with clindamycin or from untreated hamsters and BHI broth. Inoculated material was incubated for $18 \mathrm{~h}$ at $37^{\circ} \mathrm{C}$ under anaerobic conditions for $C$. difficile and aerobically for $E$. coli. The broths and emulsions were centrifuged at $1500 \mathrm{~g}$ for $20 \mathrm{~min}$ at $4^{\circ} \mathrm{C}$, washed twice in Tris-buffered saline (TBS; $50 \mathrm{mM} \mathrm{NaCl}, 0.1 \mathrm{M}$ Tris$\mathrm{HCl}, \mathrm{pH} 7.2$ ), resuspended in $10 \mathrm{ml}$ of TBS and standardised by addition of TBS to an optical density of 0.9 at $580 \mathrm{~nm}\left(\mathrm{OD}_{580}\right.$ of $0.9=10^{7} \mathrm{cfu} / \mathrm{ml}$ for $C$. difficile and $10^{9} \mathrm{cfu} / \mathrm{ml}$ for $E$. coli) for all experiments other than labelling with charged gold.

\section{Animals and preparation of caecal filtrates}

Adult female Syrian hamsters (Mesocrecitus auratus) weighing $150-200 \mathrm{~g}$, obtained from breeding colonies at the National Institute for Medical Research, London, were housed individually in sterilised filter-lidded polycarbonate boxes (Stephen Clark Fabrications Ltd, Alva, Scotland) and given autoclaved bedding, feed and tap water [9]. Some animals were given one intraperitoneal injection of $0.5 \mathrm{ml}$ of a solution of clindamycin phosphate (Upjohn, Crawley, West Sussex) $10 \mathrm{mg} / \mathrm{ml}$. Thirteen days later the animals were killed, their caeca were removed, and the caecal contents from untreated and clindamycin-treated hamsters were mixed separately with distilled water to give 1 in $20 \mathrm{w}: \mathrm{v}$ suspensions which were sterilised by centrifugation and filtration as described in detail previously [16]. These were termed normal caecal content filtrates (NH-CCF) and filtrates from clindamycin-treated hamsters (CTHCCF).

\section{Hydrophobicity}

Three methods were used to determine the hydro- phobicity of $C$. difficile strains; bacterial adhesion to hydrocarbons (BATH) [17], the salt aggregation test (SAT) [18], and hydrophobic interaction chromatography (HIC) [19]. E. coli strains U1 and O157:H7 were used as positive controls in all three methods as the majority of $E$. coli from human sources are hydrophobic [20]. Before use, these isolates were confirmed as hydrophobic by the SAT test, which is a good measure of hydrophobicity for E. coli [18]. For BATH and SAT the bacteria were harvested from NH-CCF, CTH-CCF and BHI broths. For HIC the bacteria were harvested only from BHI broths. All experiments were done in triplicate and values given are means of triplicate experiments.

BATH method. Three $\mathrm{ml}$ of each bacterial suspension were added to $3 \mathrm{ml}$ of octan-1-ol (BDH) and separately to $3 \mathrm{ml}$ of hexadecane $(\mathrm{BDH})$, in sterile tubes and vortex mixed for $2 \mathrm{~min}$, then left to stand at room temperature until the two phases had separated $(c .1 \mathrm{~h})$. The absorbance of the bacterial aqueous phase was measured at $580 \mathrm{~nm}$. Controls consisted of $3 \mathrm{ml}$ of phosphate-buffered saline (PBS; $0.15 \mathrm{M} \mathrm{NaCl}, 0.01 \mathrm{M}$ phosphate buffer, $\mathrm{pH} 7.2$ ) in place of the octan-1-ol or hexadecane to establish the absorbance of the initial bacterial suspension. The percentage hydrophobicity was calculated by the formula

$$
\frac{\mathrm{ODi}-\mathrm{ODe}}{\mathrm{ODi}} \times 100
$$

where ODi is the initial reading of the bacterial suspension and $\mathrm{ODe}$ is the reading of the aqueous phase.

The condition of the bacterial cells in the aqueous phase after partitioning in the hexadecane system was examined by electronmicroscopy as described below for determination of surface charge distribution, but without reaction with charged colloidal gold.

SAT test. Concentrations of ammonium sulphate in sodium phosphate buffer $(\mathrm{pH} 6.8,0.02 \mathrm{M})$, ranging from $4 \mathrm{M}$ to $0.02 \mathrm{M}$ in increments of $0.02 \mathrm{M}$, were prepared before the experiment. Ten $\mu$ l of each bacterial suspension were spotted on glass slides containing $10 \mu \mathrm{l}$ of the different salt concentrations in the micro-method adaptation of the SAT [13], and then rocked gently until aggregation was observed (c. $2 \mathrm{~min}$ ). The last dilution at which aggregation occurred was recorded.

HIC test. Sterile 5-ml plastic syringes were plugged with siliconised glass wool and packed to a height of $20 \mathrm{~mm}$ with octyl-Sepharose CL-4B (Sigma) in an equal volume of $0.01 \mathrm{M}$ phosphate buffer $(\mathrm{pH} 6.8)$ containing Triton $\mathrm{X}-100 \quad 0.1 \% \quad \mathrm{v} / \mathrm{v}$ (equilibration buffer). The column was washed with 20 bed-volumes of sterile $4 \mathrm{M} \mathrm{NaCl}$ solution. The bacterial strains $C$. difficile B-1 and E. coli $\mathrm{U} 1$ were suspended in $2 \mathrm{ml}$ of the same solution and absorbance at $580 \mathrm{~nm}$ was 
measured, then a $2 \mathrm{ml}$ suspension was loaded on separate columns for each strain. Elution was with $6 \mathrm{ml}$ of equilibration buffer. The absorbance readings of the 2-ml eluates were measured at $580 \mathrm{~nm}$, the first $2-\mathrm{ml}$ void volume being discarded. The percentage hydrophobicity was calculated as described above for the BATH method, where ODi was the reading of the 2-ml bacterial suspensions before loading on to the column and ODe was the reading of the last 2-ml eluates. In addition, the HIC method was repeated for all test strains in solutions of lower ionic strength (i.e. PBS), as a measure of interaction when both charge and hydrophobicity are involved.

\section{Net cell surface charge}

The overall net bacterial cell surface charge of the C. difficile strains was assessed by three methods; charged partition [21], paper electrophoresis [22] and a novel method of observation by microscopy of movement in a charged field (OM-MCF).

Charged partition. For this method polyethyleneglycol (PEG) (Sigma) 4.4\% w/v and dextran (Sigma) $6.2 \% \mathrm{w} / \mathrm{v}$ were prepared in $0.03 \mathrm{M}$ Tris- $\mathrm{HCl}$,

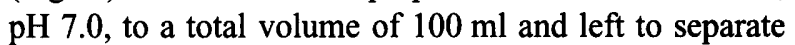
overnight at $4{ }^{\circ} \mathrm{C}$ in a separating funnel. The dextranrich bottom phase and the PEG-rich top phase were collected and stored separately at $4{ }^{\circ} \mathrm{C}$ until needed. The charged system was prepared by adding sodium sulphate to equal volumes of the two phases to give a final salt concentration of $0.1 \mathrm{M}$. The two phases were re-mixed, left to separate and stored as above. To determine the net bacterial charge $3 \mathrm{ml}$ of each phase were dispensed into a sterile tube, $1 \mathrm{ml}$ of a suspension of $C$. difficile strain B-1 (see above), after growth in BHI, was added, and the mixture was vortex mixed for $2 \mathrm{~min}$ and left to separate into the two phases. An uncharged system was prepared as a control with $\mathrm{NaCl}$ replacing the sodium sulphate. The optical density of each phase was then measured at $580 \mathrm{~nm}$. This was repeated for E. coli strain U1.

Paper electrophoresis method. The bacterial suspension after growth in BHI was spotted on the centre of dry, sterile filter paper (Whatman) strips $(1 \times 8 \mathrm{~cm})$, laid on a horizontal gel electrophoresis bed with PBS as running buffer. The ends of the paper strips were immersed in the buffer. A current of $5 \mathrm{~mA}$ was applied for $c .5 \mathrm{~min}$, the paper strip removed and carefully inverted on the surface of a Columbia agar plate with horse blood (CBA, Unipath) $10 \%$. This was repeated for each of the bacterial strains and the agar plates were incubated overnight at $37^{\circ} \mathrm{C}$ anaerobically.

OM-MCF method. Bacteria harvested from CBA after growth for $48 \mathrm{~h}$ or BHI after growth for $18 \mathrm{~h}$ were resuspended in $40 \mathrm{mM}$ Tris- $\mathrm{HCl}$ in saline $0.85 \%, \mathrm{pH}$ 7.0. Fifty $\mu \mathrm{l}$ of the suspension were applied to the centre of a conventional glass coverslip to make contact with two filter paper strips soaked in the suspension medium that ran from the centre to each end of the slide. These served as wicks which made contact to termini. This apparatus was placed under a light microscope and a glass coverslip and immersion oil were applied in the conventional manner. The positive and negative leads of a power pack (BioRad) were connected to the termini and while the bacteria were viewed under phase contrast the power pack was switched on (current $10 \mathrm{~mA}$ ) and the direction of movement of the bacteria was recorded. As the microscope optics cause lateral inversion of the image a movement to the negative or positive terminal is indicative of a negative or positive charge, respectively.

To determine whether or not any charge seen was due entirely to cell-wall constituents a cell-wall deficient mutant (autoplast) of strain $\mathrm{M}-1$ was made as described for the generation of autoplasts for $C$. perfringens [23]. In these experiments the suspension medium contained sucrose to a final concentration of $0.4 \mathrm{M}$ to maintain autoplast integrity. The parent M-1 strain was examined in a similar suspension medium as a control.

In all experiments the polarity was reversed to confirm the bacterial charge, and negatively charged carboxylated microspheres (1-6 $\mu$ diameter; Polysciences Ltd, Northampton) were used as controls.

\section{Cell surface charge distribution}

Charged colloidal gold was used to assess the topographical distribution of anionic and cationic charges on the cell surface of $C$. difficile strain B-1 and $E$. coli $0157: \mathrm{H} 7$ by electronmicroscopy. The cultures were harvested from BHI broth after growth for $18 \mathrm{~h}$ and pelleted by centrifugation at $1500 \mathrm{~g}$ for $20 \mathrm{~min}$, washed once in PBS and re-pelleted. Cationic colloidal gold (Biocell) with a mean diameter of $10 \mathrm{~nm}$, was diluted in PBS with bovine serum albumin (BSA) $1 \%(\mathrm{pH} \mathrm{7.0)}$ to give a final concentration of 1 in 10 and left at room temperature for $1 \mathrm{~h}$. The bacteria were pelleted by centrifugation at $1500 \mathrm{~g}$ for $10 \mathrm{~min}$ at $4^{\circ} \mathrm{C}$ and washed with PBS. A droplet $(25 \mu \mathrm{l})$ of each bacterial suspension was placed on 200 mesh formvarcarbon coated gold grids and left for $c$. $5 \mathrm{~min}$, to allow adherence of the cells to the grid. The grid was blotted dry and floated on glutaraldehyde $3 \%$ in $0.1 \mathrm{M}$ phosphate buffer $(\mathrm{pH} 7)$ for at least $2 \mathrm{~min}$ to fix the cells and then washed three times by floating on distilled water. The grid was then blotted dry and observed with a Jeol 1200EX transmission electronmicroscope. Exactly the same procedure was used for anionic gold labelling except that the anionic gold had to be prepared as it is not commercially available. The anionic gold was made by conjugating $10 \mathrm{~nm}$ colloidal gold (Biocell) to acetylated BSA, (Promega, $1 \mathrm{mg} / \mathrm{ml}$ solution). The $\mathrm{pH}$ of the colloidal gold was adjusted with $0.2 \mathrm{M} \mathrm{K}_{2} \mathrm{CO}_{3}$ to $\mathrm{pH} 9.0$ and acetylated BSA 
$40 \mu \mathrm{g} / \mathrm{ml}$ (with allowance for a $10 \%$ excess) was added to the colloidal gold, which was then centrifuged at $24000 \mathrm{~g}$ at $4^{\circ} \mathrm{C}$ for $30 \mathrm{~min}$. The minimal amount of acetylated BSA needed to stabilise the gold from aggregation by salt was determined as described by Roth [24]. The conjugate was resuspended in PBS and stored at $4^{\circ} \mathrm{C}$ after the addition of $2 \times 10^{-3} \mathrm{M}$ azide. At least 25 cells from unstained grids were examined to determine the mean labelling per cell. Unstained grids were used to determine the mean labelling density as negative stain obscures some of the gold particles. Cells were then negatively stained with potassium phosphotungstate $1 \%(\mathrm{pH} 6.5)$ for $10 \mathrm{~s}$ to improve contrast for photography.

\section{Haemagglutination assay}

In addition to bacterial suspensions prepared after growth in BHI, NH-CCF and CTH-CCF, the test strains were also harvested in PBS, after anaerobic incubation on CBA for $48 \mathrm{~h}$, pelleted and washed twice in PBS and standardised in PBS to an $\mathrm{OD}_{580}$ of 0.9. Five-ml blood samples from normal horse, sheep, turkey, goose, chicken (Tissue Cultures Services, Botolph Claydon, Bucks), hamster, pig, rat, goat, mouse, guinea-pig and rabbit (obtained from animals housed on site) and human blood group $\mathrm{A}^{+}, \mathrm{O}^{+}$and $\mathrm{B}^{+}$(obtained from healthy volunteers) were stored in Alsever's solution $(0.03 \mathrm{M}$ sodium citrate, $0.11 \mathrm{M}$ glucose, $0.07 \mathrm{M} \mathrm{NaCl}$, $\mathrm{pH} 6.1$ ) at $4^{\circ} \mathrm{C}$. Uninoculated NH-CCF and CTH-CCF and sham harvests from CBA plates were used as medium controls and $E$. coli strain U1 which is known to haemagglutinate (data not shown) as a positive control. Before use the red blood cells (RBC) were washed twice with TBS, resuspended in the buffer to give an RBC suspension of $1 \% \mathrm{v} / \mathrm{v}$, and $50 \mu \mathrm{l}$ of the RBC suspension for each blood type were added to $50 \mu \mathrm{l}$ of two-fold serially diluted bacterial suspensions in 96-well, round-bottomed microtitration plates (SeroWell; Sterilin, Stone, Staffs). The plates were set up in triplicate with one plate incubated at room temperature, one at $37^{\circ} \mathrm{C}$ and one at $4^{\circ} \mathrm{C}$. $\mathrm{RBC}$ suspensions $(1 \% \mathrm{v} / \mathrm{v}$ in TBS) were also treated with Vibrio cholerae neuraminidase (Behring) $0.1 \mathrm{unit} / \mathrm{ml}$ for $2 \mathrm{~h}$ at $37^{\circ} \mathrm{C}$ to expose backbone sequences. In addition, human blood group B RBCs were also incubated with $\alpha$ fucosidase (Sigma) 0.2 units $/ \mathrm{ml}$ for $2 \mathrm{~h}$ at room temperature to remove fucose moieties and reveal $\mathrm{Gal}$ $\alpha 1-3$ B-like structures. The RBCs were then pelleted by centrifugation at $1500 \mathrm{~g}$ for $5 \mathrm{~min}$, washed twice in TBS buffer and resuspended to give a $1 \%$ suspension. Control RBCs were processed in the same way, with TBS in place of the neuraminidase and $\alpha$-fucosidase.

\section{Statistical analysis}

Results were compared for statistical difference by a one-way analysis of variance.

\section{Results}

\section{Hydrophobicity}

The results are presented in Table 1. After culture in BHI broths the partition method of assessing hydrophobicity indicated greater hydrophobicity for all strains when hexadecane rather than octan-1-ol was used as the non-aqueous phase, this difference being greatest for $C$. difficile strain $\mathrm{M}-1$. In all cases the percentage hydrophobic values for $C$. difficile by the partition method were similar to those of $E$. coli, with the exception of $C$. difficile strain 8864 which was less hydrophobic. Analysis by electronmicroscopy of $C$. difficile cells isolated from the aqueous phase after partition in hexadecane revealed cell-wall damage as indicated by complete uptake of negative stain. In

Table 1. Hydrophobicity of $C$. difficile and $E$. coli and the effects of culture in different media

\begin{tabular}{|c|c|c|c|c|c|c|c|c|}
\hline \multirow[b]{2}{*}{ Bacterial strain } & \multirow[b]{2}{*}{ Preparation } & \multicolumn{3}{|c|}{$\begin{array}{c}\text { Mean }(\mathrm{SD})^{*} \text { percentage hydrophobicity } \\
\text { by partition method }\end{array}$} & \multirow{2}{*}{\multicolumn{2}{|c|}{$\begin{array}{l}\text { Salt agglutination } \\
\text { test (lowest } \mathrm{M} \\
\text { value showing } \\
\text { agglutination) (SD) }\end{array}$}} & \multicolumn{2}{|c|}{$\begin{array}{l}\text { Hydrophobic interaction chromatograph } \\
\text { (percent of cells retained) (SD) }\end{array}$} \\
\hline & & \multirow{2}{*}{$\frac{\text { octan-1-ol }}{43 \%(0.6)}$} & \multicolumn{2}{|c|}{ hexadecane } & & & \multirow{2}{*}{$\frac{\text { PBS }}{55 \%(1.0)}$} & $4 \mathrm{M} \mathrm{NaCl}$ \\
\hline \multirow[t]{3}{*}{ C. difficile VPI 10463} & $\mathrm{a}$ & & $49 \%$ & $(0.6)$ & 3.1 & $(0.1)$ & & $\ldots$ \\
\hline & b & $44 \%(1.5)$ & $52 \%$ & $(0.6)$ & 2.3 & $(0.3)$ & & \\
\hline & c & $40 \%(0.6)$ & $47 \%$ & $(1.0)$ & 3.1 & $(0.1)$ & & \\
\hline \multirow[t]{3}{*}{ B-1 } & a & $32 \%(1.0)$ & $46 \%$ & $(1.0)$ & 3.0 & $(0 \cdot 0)$ & $43 \%(3.0)$ & $72 \%(2.0)$ \\
\hline & b & $28 \%(0.6)$ & $46 \%$ & $(1.0)$ & 3.0 & $(0.1)$ & & \\
\hline & c & $30 \%(1.0)$ & $49 \%$ & $(0.6)$ & 2.0 & $(0.0)$ & & \\
\hline \multirow[t]{3}{*}{ BAT } & a & $30 \%(1.0)$ & $43 \%$ & $(0.6)$ & 2.2 & $(0 \cdot 2)$ & $41 \%(1.5)$ & $\ldots$ \\
\hline & b & $33 \%(1.0)$ & $45 \%$ & $(0.0)$ & 2.0 & $(0.0)$ & & \\
\hline & c & $29 \%(0.6)$ & $42 \%$ & $(0.5)$ & 3.0 & $(0.0)$ & & \\
\hline \multirow[t]{3}{*}{8864} & $\mathbf{a}$ & $20 \%(1.0)$ & $28 \%$ & (1.1) & 3.1 & $(0.1)$ & $31 \%(2.5)$ & $\ldots$ \\
\hline & $\mathbf{b}$ & $22 \%(1.5)$ & $25 \%$ & $(0.0)$ & 3.0 & $(0.0)$ & & \\
\hline & c & $25 \%(1.5)$ & $22 \%$ & (1.1) & 3.0 & $(0.0)$ & & \\
\hline \multirow[t]{3}{*}{ M-1 } & $\mathbf{a}$ & $27 \%(1.0)$ & $51 \%$ & (1.1) & 4.1 & $(0 \cdot 1)$ & $41 \%(2.6)$ & $\ldots$ \\
\hline & b & $26 \%(1.1)$ & $53 \%$ & $(0.6)$ & 3.1 & $(0.1)$ & & \\
\hline & c & $28 \%(1.0)$ & $49 \%$ & $(1.5)$ & 4.0 & $(0.0)$ & & \\
\hline E. coli $\mathrm{U} 1$ & $\mathrm{a}$ & $36 \%(1.5)$ & $48 \%$ & $(0.1)$ & $0.5 \%$ & $(0.1)$ & $65 \%(2.0)$ & $66 \%(2.0)$ \\
\hline O157:H7 & $\mathbf{a}$ & $38 \%(2.5)$ & $50.7 \%$ & (5.1) & $0.9 \%$ & $(0.2)$ & $85 \%(2.0)$ & $\ldots$ \\
\hline
\end{tabular}

a, BHI broth; b, filtrate of normal hamster caecal contents (NH-CCF); c, filtrate of clindamycin-pre-treated hamster caecal contents (CTHCCF); PBS, phosphate-buffered saline.

*SD of triplicate mean values. 
contrast, the results of the salt agglutination test clearly distinguished between the two species with all of the $C$. difficile strains agglutinating only at high salt concentrations (hydrophilic) and the two E. coli strains agglutinating at low salt concentrations (hydrophobic). However, HIC (with solutions of high ionic strength to remove the effect of charge) showed $C$. difficile strain B-1 to be as hydrophobic as E. coli strain U1. The HIC test conducted in the presence of solutions of lower ionic strength indicated that both $E$. coli test strains were retained by the octyl-sepharose better than any of the $C$. difficile strains.

To determine whether or not growth of $C$. difficile in conditions more reflective of those found within the gut would alter cell surface hydrophobicity the strains were re-examined by the salt agglutination test and partition method after growth in caecal emulsions. In all cases the findings were similar to those obtained after growth in BHI broth (Table 1).

\section{Net cell surface charge}

In the partition method of net cell surface charge determination (Table 2) C. difficile B-1 (chosen as a representative strain), and $E$. coli strain U1 were significantly more attracted to the positively charged PEG phase than to the negatively charged dextran phase $(p<0.001)$, indicative of a net negative charge at $\mathrm{pH} 7$. However, this partitioning was significantly less than for the negatively charged $E$. coli $\left(\mathrm{OD}_{580} 0.41\right.$ versus $0.19 ; \mathrm{p}<0.001$ ), with the $\mathrm{OD}_{580}$ absorbance value of 0.19 for $C$. difficile in the PEG phase being similar to that of 0.14 in the uncharged system $(\mathrm{p}=0.06)$. For $E$. coli, the difference between the charged and uncharged PEG system was significant $(p=0.002)$. In contrast, overall movement determined by paper electrophoresis of all five $C$. difficile strains in a charged field was towards the cathode, indicative of a net positive charge. However, a few cells had moved to the anode, showing that some cells present carried an overall negative charge. The OM-MCF method showed all $C$. difficile strains had a net positive charge. The autoplasts of strain M-1 moved very slowly compared to the other strains and the M-1 parent strain control in sucrose, indicative of a weak net positive charge.

\section{Cell surface charge distribution}

There was a fairly even distribution of gold particles on the cell surface of $C$. difficile B-1 after interaction with anionic colloidal gold (Fig. 1a) with $83.3 \%$ of the cells labelled at a mean of 74.6 particles/cell (range 7-210), whereas there was little labelling of E. coli $0157: \mathrm{H} 7$ (Fig. 1b), with $39.0 \%$ of cells labelled (mean 23.0 particles; range 1-204). In contrast, few $C$. difficile cells were labelled with cationic colloidal gold (Fig. 1c) and these had few gold particles associated with them (35.0\% of cells labelled with a mean of 5.2 particles/ cell; range 1-23). The majority of E. coli $0157: \mathrm{H} 7$ cells showed heavy labelling with cationic colloidal gold (Fig. 1d) with $96.1 \%$ of cells labelled with a mean of 50.1 particles/cell; range 1-161.

\section{Haemagglutination}

After being washed twice none of the five $C$. difficile strains assayed haemagglutinated any of the 15 RBC types from 13 different animal species at any of the test temperatures. This same pattern of lack of haemagglutination was also seen after the RBCs had been treated with neuraminidase or $\alpha$-fucosidase. $C$. difficile washed only once after growth in caecal content filtrates and on CBA plates agglutinated porcine, rabbit and goat RBCs at $37^{\circ} \mathrm{C}$. However, this pattern of haemagglutination was also evident with uninoculated caecal content filtrates and sham harvests from CBA agar plates. The $E$. coli strain $\mathrm{U} 1$ positive control haemagglutinated rabbit, sheep and human $\left(\mathrm{A}^{+}, \mathrm{B}^{+}, \mathrm{O}^{+}\right.$blood group) RBCs.

\section{Discussion}

The interaction of bacteria with cell surfaces or secreted products of the host is considered to be the end result of a complex set of interactions involving both attractive and repulsive forces operating between target cells or cell products and the bacterial cell surface [25]. In addition to the accepted contribution of adhesin-receptor interactions, there is some evidence to implicate hydrophobic interactions and net charge [26]. Additional factors include access to receptors and chemotaxis of the bacterial cell. Of the physicochemical factors, electrostatic forces are considered to be the

Table 2. Net cell surface charge determined by partition between polyethyleneglycol and dextran for $C$. difficile B-1 and $E$. coli strain U1

\begin{tabular}{lllll}
\hline & \multicolumn{4}{c}{ Mean $\mathrm{OD}_{580}(\mathrm{SD})$ of triplicate experiments } \\
\cline { 2 - 6 } System & \multicolumn{3}{c}{ Polyethylene-glycol } & \multicolumn{2}{c}{ Dextran } \\
\cline { 2 - 6 } & C. difficile & E. coli & C. difficile & E. coli \\
\hline Charged & $0.19(0.01)$ & $0.41(0.01)$ & $0.08(0.006)$ & $0.04(0.007)$ \\
Uncharged & $0.14(0.01)$ & $0.17(0.007)$ & $0.18(0.006)$ & $0.16(0.007)$ \\
\hline
\end{tabular}

${ }^{*} \mathrm{OD}_{580}$ triplicate mean value $\pm \mathrm{SD}$. 

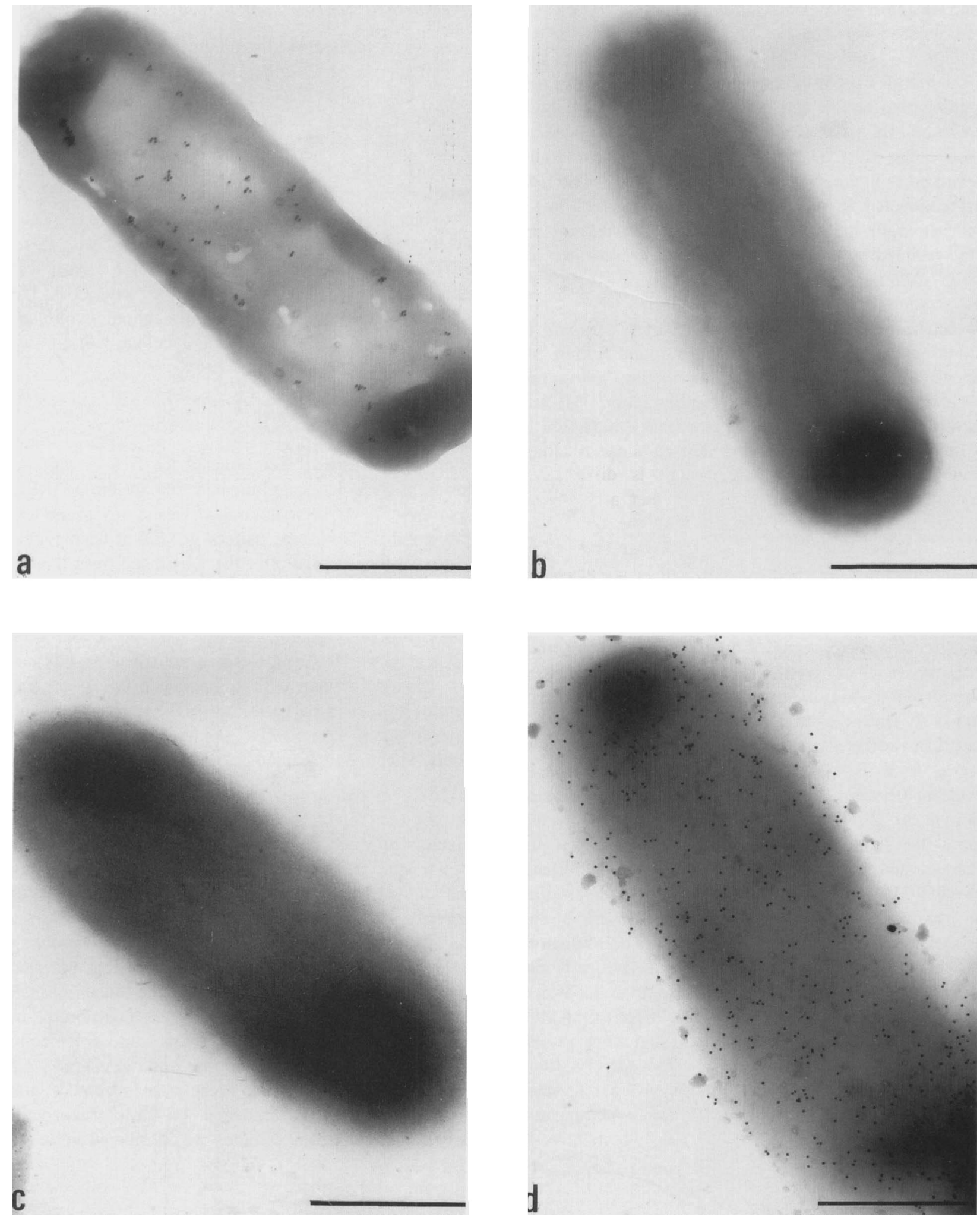

Fig. 1. Electronmicroscopic analysis of cell surface charge of $C$. difficile strain B-1 and $E$. coli O157:H7. Detection of positive charge on a, $C$. difficile, b, E. coli with $10 \mathrm{~nm}$ anionic colloidal gold, and of negative charge on $\mathbf{c}, C$. difficile, d, E. coli, with $10 \mathrm{~nm}$ cationic colloidal gold. A few $E$. coli cells bound anionic colloidal gold (not shown).

ones that operate over the greatest distances [27] and, therefore, likely to dominate the initial interaction between a pathogen and the negatively charged host cell. These can be divided into long-range Van der
Waals interactions and medium-range electrostatic interactions. Mathematical descriptions of these and other physicochemical interactions are to be found in a review by Busscher and Weerkamp [28]. It is evident 
from the studies presented here that $C$. difficile isolates from different sources and of different virulence carry a net positive cell surface charge with movement to the cathode in a charged field (paper electrophoresis and OM-MCF methods). In contrast, the charged partition method showed movement of $C$. difficile to the positive phase indicative of a net negative cell surface charge. However, this degree of partitioning was much less than for the $E$. coli strain which was negatively charged as determined by binding to charged gold particles. This observation is in keeping with the net negative charge of most bacteria [29]. Further support for a net positive charge for $C$. difficile comes from the electronmicroscopic observations of interaction with charged gold particles which showed that the vast majority of cells carried only a positive charge, and that the charge was evenly distributed over the cell surface. However, a few cells possessed some negative charge. The extent to which these cells may have a predominant weakly negative charge is difficult to determine, although direct evidence that a few such cells in a population exist comes from the fact that a small number of cells migrated to the anode in the paper electrophoresis method. The implication of the above finding is that there may be net charge heterogeneity within a population of $C$. difficile cells. The slow migration of autoplasts of strain M-1 towards the cathode showed that most of the contribution to net charge came from cell-wall components. The decreased rate of migration was not due to the viscosity of the autoplast suspension medium or differences in its conductivity as the parent strain retained an indistinguishable rate of migration in the conventional or sucrose-containing suspension media. Therefore, intracellular components of $C$. difficile also impart a positive charge to the cells that contributes to the net charge.

Interestingly, net electrostatic charge has been correlated with virulence for the fish pathogen Aeromonas salmonicida [30]. For this pathogen there is intraspecies variation in net charge, the virulent strains possessing a net negative charge and adhering to positively charged fish cells in tissue culture better than positively charged avirulent strains.

It is generally accepted that hydrophobicity is important in the interaction of bacteria with host cells, with high bacterial cell surface hydrophobicity correlating with adhesion of oral organisms to oral cavity surfaces [31], and adhesion of gut pathogens, e.g., enteropathogenic $E$. coli adhesion to intestinal brush border membranes [32]. There has been only one previous study reporting on the hydrophobic properties of $C$. difficile [33]. That study used relative adherence to polystyrene as an indicator of hydrophobicity, and concluded that all the isolates examined were hydrophobic. The present studies with $C$. difficile strain B-1 and hydrophobic interaction chromatography confirm the hydrophobic nature of $C$. difficile.
The partition methods gave values of intermediate hydrophobicity for all strains examined (i.e., values falling between $15 \%$ and $80 \%$ ), with lower values overall for octan-1-ol as the organic phase than for hexadecane. The extent to which these values truly reflect the hydrophobicity of the intact cell is difficult to determine as electronmicroscopic examination of C. difficile recovered from the aqueous or organic phases showed that they had suffered extensive damage. In contrast, the SAT method gave the clearest distinction between $C$. difficile and $E$. coli, showing $E$. coli to be hydrophobic and $C$. difficile to be highly hydrophilic. Unfortunately, the SAT test is most reliable for detecting strongly hydrophobic microorganisms [34] and its accuracy for bacteria of intermediate hydrophobicity is unclear, although there is a good correlation between HIC and SAT determinations for $E$. coli [18]. We cannot explain why $C$. difficile strain B-1 was hydrophilic when assessed by the SAT but moderately hydrophobic when assessed by HIC.

It is known that a number of factors can affect the hydrophobicity of a bacterial cell surface, such as expression of bacterial surface components $[35,36]$, and growth conditions [37]. It is also known that bacterial surface components can be altered or surface architecture disorganised, or both, by antibiotics, particularly those such as clindamycin which perturb protein synthesis [38]. Therefore, in order to examine the possibility that the cell surface hydrophobicity of $C$. difficile differed following culture in conditions simulating those in vivo, the bacteria were examined from untreated and clindamycin-treated animals. These growth conditions had no apparent effect on the cell surface hydrophobicity of $C$. difficile as determined by either of the partition methods or the salt aggregation method.

The extent to which the presence of capsular material on $C$. difficile [5] contributes to hydrophobicity is unknown, as conflicting results have been found for other gram-positive bacteria [35, 39].

It is possible that a positive cell surface charge may contribute to the known resistance of $C$. difficile to phagocytosis [40] as decreasing negative charge has been correlated with resistance to phagocytosis [41] and conversely increases in negative cell surface charge are associated with increased susceptibility to phagocytosis [42].

In an attempt to assess the degree of binding when both charge and hydrophobic interactions were simultaneously involved, hydrophobic interaction chromatography with a relatively low ionic strength solution was performed. Interestingly, when the effect of electrostatic charge interactions was retained the degree of binding for $C$. difficile strain B-1 was lower than when electrostatic interactions were mini- 
mised by the use of high ionic strength solutions. No such difference was seen with the test $E$. coli strain used. The implication is that, at $\mathrm{pH} 7.0$, the net cell surface charge of $C$. difficile serves to reduce the amount of binding expected from hydrophobic interactions alone. Due to the weak negative charge of the octyl-sepharose CL-4B an increase in binding of $C$. difficile would have been expected. These results highlight the problem of simplistic extrapolations from charge and hydrophobicity results alone.

It was surprising that haemagglutination by $C$. difficile could not be demonstrated under any of the experimental procedures used. This is particularly so because Karjalainen et al. [11] have recently reported haemagglutination by $C$. difficile of human $\mathrm{O}^{+}, \mathrm{A}^{+}$, $\mathrm{B}^{+}$, sheep, rabbit and horse erythrocytes. These differences could be explained by differences in methodology as Karjalainen et al. [11] noted a low degree of haemagglutination; they used a slide agglutination assay whereas the microwell assay for haemagglutination was used in this study. Also, it is unclear from their study whether or not the bacteria grown on agar were washed, and to what degree, before they were examined for haemagglutinating ability. This is important as this study has shown that agar components may contribute to haemagglutination, and a similar observation has been made by others when studying haemagglutination by Helicobacter pylori [43].

In conclusion, although there is a little intra-species variability, $C$. difficile cells are of medium hydrophobicity and possess a net positive cell surface charge. These characteristics may contribute to resistance to phagocytosis and also contribute to their ability to adhere to gut mucus and underlying cells.

This work was funded by a Medical Research Council Programme Grant (No. G9122850). Part of the work was conducted at the MRC Clinical Research Centre, Harrow. Mr P. J. Reed helped in the design of the OM-MCF method of charge determination.

\section{References}

1. Borriello SP (ed). Antibiotic associated diarrhoea and colitis the role of Clostridium difficile in gastrointestinal disorders. Boston, Martinus Nijhoff Publishers. 1984.

2. Rolfe RD, Finegold SM (eds). Clostridium difficile: its role in intestinal disease. San Diego, Academic Press. 1988.

3. Borriello SP, Davies HA, Kamiya S, Reed PJ, Seddon S. Virulence factors of Clostridium difficile. Rev Infect Dis 1990; 12 Suppl 2: S185-S191.

4. Lyerly DM, Krivan HC, Wilkins TD. Clostridium difficile: its disease and toxins. Clin Microbiol Rev 1988; 1: 1-18.

5. Davies HA, Borriello SP. Detection of capsule in strains of Clostridium difficile of varying virulence and toxigenicity. Microb Pathog 1990; 9: 141-146.

6. Seddon SV, Borriello SP. Proteolytic activity of Clostridium difficile. J Med Microbiol 1992; 36: 307-311.

7. Seddon SV, Hemingway I, Borriello SP. Hydrolytic enzyme production by Clostridium difficile and its relationship to toxin production and virulence in the hamster model. $J \mathrm{Med}$
Microbiol 1990; 31: 169-174.

8. Borriello SP. Clostridium difficile and its toxins in the gastrointestinal tract in health and disease. Res Clin Forums 1979; 1(3): 33-35

9. Borriello SP, Welch AR, Barclay FE, Davies HA. Mucosal association by Clostridium difficile in the hamster gastrointestinal tract. $J$ Med Microbiol 1988; 25: 191-196.

10. Eveillard M, Fourel V, Barc M.-C et al. Identification and characterization of adhesive factors of Clostridium difficile involved in adhesion to human colonic enterocyte-like Caco-2 and mucus-secreting HT29 cells in culture. Mol Microbiol 1993; 7: 371-381.

11. Karjalainen T, Barc M.-C., Collignon A et al. Cloning of a genetic determinant from Clostridium difficile involved in adherence to tissue culture cells and mucus. Infect Immun 1994; 62: 4347-4355.

12. Borriello SP, Davies HA, Barclay FE. Detection of fimbriae amongst strains of Clostridium difficile. FEMS Microbiol Let 1988; 49: 65-67.

13. Borriello SP, Barclay FE. Protection of hamsters against Clostridium difficile ileocaecitis by prior colonisation with non-pathogenic strains. J Med Microbiol 1985; 19: 339-350.

14. Borriello SP, Ketley JM, Mitchell TJ et al. Clostridium difficile - a spectrum of virulence and analysis of putative virulence determinants in the hamster model of antibiotic-associated colitis. J Med Microbiol 1987; 24: 53-64.

15. Borriello SP, Wren BW, Hyde S et al. Molecular, immunological, and biological characterization of a toxin A-negative, toxin B-positive strain of Clostridium difficile. Infect Immun 1992; 60: 4192-4199.

16. Borriello SP, Barclay FE. An in-vitro model of colonisation resistance to Clostridium difficile infection. $J$ Med Microbiol 1986; 21: 299-309.

17. Rosenberg M, Gutnick D, Rosenberg E. Adherence of bacteria to hydrocarbons: a simple method for measuring cell-surface hydrophobicity. FEMS Microbiol Lett 1980; 9: 29-33.

18. Lindahl M, Faris A, Wadstrom T, Hjerten S. A new test based on "salting-out" to measure relative surface hydrophobicity of bacterial cells. Biochim Biophys Acta 1981; 677: 471-476.

19. Ismaeel N, Furr JR, Pugh WJ, Russell AD. Hydrophobic properties of Providencia stuartii and other gram-negative bacteria measured by hydrophobic interaction chromatography. Lett Appl Microbiol 1987; 5: 91-95.

20. Faris A, Wadström T, Freer JH. Hydrophobic adsorptive and haemagglutinating properties of Escherichia coli possessing colonization factor antigens (CFA/1 or CFA/II), type 1 pili or other pili. Curr Microbiol 1981; 5: 67-72.

21. Miörner H, Albertsson P-A, Kronvall G. Isoelectric points and surface hydrophobicity of gram-positive cocci as determined by cross-partition and hydrophobic affinity partition in aqueous two-phase systems. Infect Immun 1982; 36: 227-234.

22. Sakai DK. Kinetics of adhesion associated with net electrical charges in agglutinating Aeromonas salmonicida cells and their spheroplasts. Bull Jpn Soc Sci Fisheries 1986; S2: 31-36.

23. Heefner DL, Squires CH, Evans RJ, Kopp BJ, Yarus MJ. Transformation of Clostridium perfringens. J Bacteriol 1984, 159: $460-464$

24. Roth $\mathrm{J}$. The protein A-gold (pAg) technique: a qualitative and quantitative approach for antigenic localisation on thin sections. In: Bullock GR, Petrusz $P$ (eds) Techniques in immunocytochemistry, vol 1. London, Academic Press. 1982: 107.

25. Ofek I, Beachey EH. General concepts and principles of bacterial adherence in animals and man. In: Beachey EH (ed) Bacterial adherence. Receptors and recognition, series $B$ vo 16. London, Chapman and Hall. 1980: 1.

26. Edebo L, Kohlström E, Magnusson K-E, Stendahl O. The hydrophobic effect and charge effects in the adhesion of enterobacteria to animal cell surfaces and the influences of antibodies of different immunoglobulin classes. In: Curtis ASG, Pitts $H$ (eds) Cell adhesion and motility (The third symposium of the British Society for Cell Biology). Cambridge, Cambridge University Press. 1980: 65-101.

27. Curtiss ASG. Cell adhesion. In: Butler JAV, Nobel D (eds) Progress in biophysics and molecular biology, vol 27. Oxford Pergamon Press. 1973: 315-386.

28. Busscher HJ, Weerkamp AH. Specific and non-specific interactions in bacterial adhesion to solid substrata. FEMS Microbiol Rev 1987; 46: 165-173.

29. van Loosdrecht MCM, Lyklema J, Norde W, Schraa G 
Zehnder AJB. Electrophoretic mobility and hydrophobicity as a measure to predict the initial steps of bacterial adhesion. Appl Environ Microbiol 1987; 53: 1898-1901.

30. Sakai DK. Adhesion of Aeromonas salmonicida strains associated with net electrostatic charges of host tissue cells. Infect Immun 1987; 55: 704-710.

31. Weiss E, Rosenberg M, Judes H, Rosenberg E. Cell surface hydrophobicity of adherent oral bacteria. Curr Microbiol 1982; 7: $125-128$.

32. Cantey JR, Lushbaugh WB, Inman LR. Attachment of bacteria to intestinal epithelial cells in diarrhea caused by Escherichia coli strain RDEC-1 in the rabbit: stages and role of capsule. $J$ Infect Dis 1981; 143: 219-230.

33. Wood-Helie SJ, Dalton HP, Shadomy S. Hydrophobic and adherence properties of Clostridium difficile. Eur J Clin Microbiol 1986; 5: 441-445.

34. Mozes N, Rouxhet PG. Methods for measuring hydrophobicity of microorganisms. J Microbiol Methods 1987; 6: 99-112.

35. Ofek I, Wnitnack E, Beachey EH. Hydrophobic interactions of Group A streptococci with hexadecane droplets. $J$ Bacteriol 1983; 154: 139-145.

36. Rosenberg E, Kaplan N, Pines O, Rosenberg M, Gutnick D. Capsular polysaccharides interfere with adherence of Acinetobacter calcoaceticus to hydrocarbons FEMS Microbiol Lett
1983; 17: $157-160$.

37. Rosenberg M, Rosenberg E, Judes H, Weiss E. Bacterial adherence to hydrocarbons and to surfaces in the oral cavity. FEMS Microbiol Lett 1983; 20: 1-5.

38. Schifferli DM, Beachey EH. Bacterial adhesion: modulation by antibiotics which perturb protein synthesis. Antimicrob Agents Chemother 1988; 32: 1603-1608.

39. Bruce DL, Fisher D, Hart CA. The partitioning of Staphylococcus epidermidis in aqueous two-phase systems. $J$ Med Microbiol 1987; 24: 181-184.

40. Dailey DC, Kaiser A, Schloemer RH. Factors influencing the phagocytosis of Clostridium difficile by human polymorphonuclear leukocytes. Infect Immun 1987; 55: 1541-1546.

41. Magnusson KE, Stendahl O, Tagesson C, Edebo L, Johansson G. The tendency of smooth and rough Salmonella typhimurium bacteria and lipopolysaccharide to hydrophobic and ionic interaction, as studied in aqueous two-phase systems. Acta Pathol Microbiol Scand B 1977; 85: 212-218.

42. Stendahl O, Edebo L. Phagocytosis of mutants of Salmonella typhimurium by rabbit polymorphonuclear cells. Acta Pathol Microbiol Scand B 1972; 80: 481-488.

43. Huang J, Smyth CJ, Kennedy NP, Arbuthnott JP, Keeling PWN. Haemagglutinating activity of Campylobacter pylori. FEMS Microbiol Lett 1988; 56: 109-112. 